\title{
Reverend Mother and Tamar (Gn 38) trapped between 'artificial' barrenness and 'normative' motherhood: Any fitting biblical hermeneutic?
}

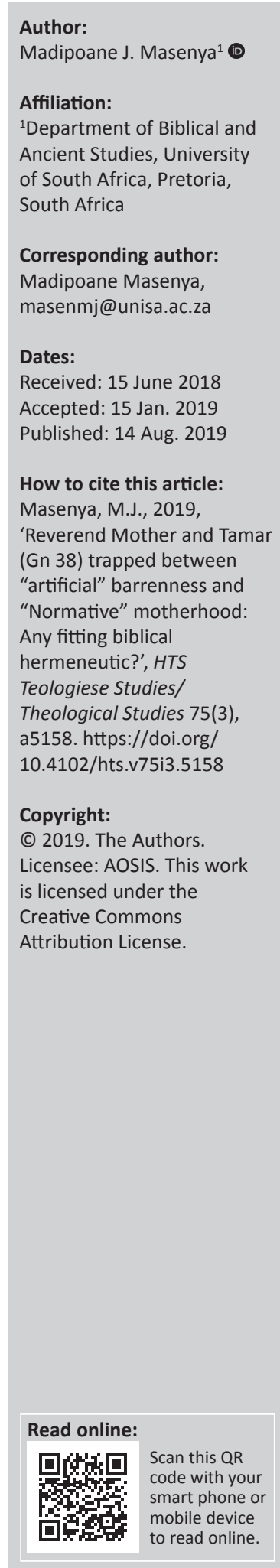

Reverend Mother's entry into ordained ministry did not quench her maternal instinct to experience the fruit of her own body. Her craving was thus not for a man as a husband but for a baby, the fruit of her own womb. As a result of her unconventional choice to fulfil her desire technologically, the church '[...] stripped her of her authority, position, and title' (Henry 2010). In many a family-oriented, communal, hetero-patriarchal (African) Christian setting, a setting in which many a woman, persuaded by a specific biblical hermeneutic, finds herself trapped between 'artificial' infertility and a deep desire to have a baby, what kind of hermeneutic may emerge if Genesis 38 is read side by side with Reverend Mother's narrative? The present article is an attempt to engage the preceding question critically.

Keywords: Nora; Tamar; Judah; Levirate marriage; Motherhood; Artificial insemination; Genesis 38.

\section{Introduction}

With the advancements in technology, the conventional concept of motherhood ${ }^{1}$ has come to resist simple, neat definitions. The role of mothers, especially as it is performed by women, is contested in many circles which set great store by the rights of women as equal human beings. Feminist theologian, Rosemary Radfort Ruether (1995), for example, advocates for joint mothering. As it will become evident in the introductory section of this article, the advent of democracy and modern technology has also ushered in new dynamics around the concept of motherhood. The complex nature of the definition of gender (cf. the categories of Lesbian, Gay, Bisexual, Transgender, Queer, Intersex+ persons) also brings new, unique dynamics to conventional notions of motherhood. Perhaps, it is no coincidence that this article, which seeks to celebrate the scholarship of a colleague and a 'son' who used to call me Matro, that is, Professor Eben H. Scheffler, should engage the concept of motherhood.

In the first section, I give a brief overview of the contents of the book written by Eron Henry, titled Reverend Mother (Henry 2010a). The focus will be on the character Nora, as being trapped between the Christian Reformed Church of Jamaica's (CRCJ) notions of conception, childbearing and motherhood and conception from assisted reproduction technologies. From the Jamaican (Africana/global) cultural perspective(s) and, in particular, from the CRCJ's perspective, childbearing and motherhood ought to happen only within a heterosexual marriage union.

\section{Glimpsing Nora's story}

At the beginning of her narrative, the reader meets Nora as a 12-year-old girl, with two male siblings. Her desire is to become a principal like Mrs Logan, but only at a bigger school. Jean Kellier, one of the most left-leaning teachers, hosts Nora in her house as Nora's school was far away from her home. Nora's stay with Kellier would impact on her political life later on (Henry 2010:1-25). 1.The concept of motherhood as it is used in this article basically refers to the conventional or traditional notion of woman as being
biologically capable to conceive, deliver and then mother a baby. What makes the concept contested, especially within (white) feminist
circles, is how in patriarchal contexts, womanhood has always been tied to the traditional roles of mother and wife in heterosexual
marriages. As I have engaged the concept of woman as mother elsewhere, especially in African settings, a few references in this regard will be in order (Masenya [Ngwana' Mphahlele] 2004, 2010).

Note: The collection entitled 'Eben Scheffler Festschrift', sub-edited by Jurie H. le Roux (University of Pretoria) and Christo Lombaard (University of South Africa). 
Nora gets appointed as the deputy general secretary and the editor of the Workers Congress Party (WCP).

She organises an evening forum in which the WCP is engaged with a view to entrenching socialist and communist ideals (Henry 2010:16-33). At some point, Nora decides to wander into the city at night. As she heads back home, she hears a preacher at a tent meeting preaching about confession, repentance, reconciliation and restitution. An elaborate sermon based on some of the biblical characters is given: Jesus on repentance; Paul on reconciliation; and Zacchaeus on restitution, among others (Henry 2010:60-65). After listening to the sermon, Nora ends up committing her life to Jesus Christ (Henry 2010:46-67).

Meanwhile, Nora organises a youth retreat. Her effective youth ministry is reflected in the notable growth of the number of young people in the church from 15 to 64 ! During the last session of the retreat, Alexander Thompson preaches on the call in people's lives and how several people try to ignore this call. Moses, Jeremiah and Jonah are cited as cases in point. Standing directly in front of Nora's row, the preacher reveals that there is someone who is trying to run away from his or her call, exhorting him or her to yield and keep his or her eyes on Jesus. Nora's quiet tears wash her resistance (to the call) away (Henry 2010:77-81). She then gets initiated into ministry at the Jamaica School of Theology (JST). During her first two years at the Seminary, turbulence, uncertainty, doubt and faith marked Nora's life. However, she finds solace from the patriarchal setup within womanist theology. After graduating from the Seminary, Nora is allocated a church located 3000 feet above sea level, on a mountain (Henry 2010:82-107).

There is a mood of celebration in the church as the new pastor, resourceful Nora, is being welcomed. Not only is Nora the first female minister within the Reformed Christian Church in Jamaica (RCCJ), she is also the first woman to be admitted into pastoral ministry (Henry 2010:108-112).

In a conversation with Janet, her friend, Nora makes a daring statement: 'I've decided to have a child,' Henry (2010:117). Nora wants a child, but without a man! As can be expected, Janet vehemently opposes Nora's desire to have a baby. Nora, however, is determined to go ahead with her plan irrespective of what the consequences thereof could be (Henry 2010:113-119).

The ordination ceremony in which Nora would be ordained as a pastor of the RCCJ is attended by high-profile people. Nora and three other ordinands participate in a lively, elaborate ceremony. What makes Nora's ordination special though is the fact that she is the first woman to be ordained into Christian ministry and also to be admitted as a pastor (Henry 2010:120-128).

Then, there is a long debate and questioning by the Seminary and church officials about what Nora plans to do. The opposition against artificial insemination is based on the following factors, among others: a proper family is supposed to be run by two parents; adultery; the challenge to be posed by an absent father; confusion to be caused among fellow believers; and women in ministry would be jeopardised (Henry 2010:129-141). Nora responds by describing the church as being patriarchal. In the church, many battles basically involve women and their bodies (cf. birth control, abortion, sex or childbearing). 'And it is always men who are telling us what is right from what is wrong as to what to do with our bodies, and our own sexuality' (Henry 2010:140).

Nora is then asked to recuse herself from the meeting. The discussion then focusses basically on the disapproval of the officials who elaborate on what artificial insemination basically entails. The challenge that would be posed by an absent father and the procedure used by lesbian couples are raised as points of concern, among others. When Nora is called back to the meeting, she receives a negative feedback. However, she remains firm in her convictions and intentions of what she seeks to do. The meeting encourages Nora to go for counselling within the Reformed tradition (Henry 2010:142-153).

At the first meeting of the National Council of Churches of the RCCJ, after positive feedback from Nora's counsellor about her state of mind, Nora's admission to being pregnant and her refusal to resign or to take leave, there is a recommendation that her accreditation status as a pastor be withdrawn (Henry 2010:160-162).

Meanwhile, Nora gets invited to a meeting with business and professional women. She tells her audience that hers is a female battle (Henry 2010):

I am the first to admit that what I've done is most unusual, perhaps unique. I've dared to challenge long held traditions and beliefs. What makes it especially difficult is that I'm female. A female rebel is itself an oddity in our country. But there're some battles that only a woman can fight. Men cannot fight for us, nor should we expect that they should. (p. 194)

Nora then elaborates on the predicament faced by women who are exhorted - or, rather, forced - to marry strictly within their church tradition. The main reason why she decided to follow the path of artificial insemination is because, like all other women, she wished to have a family of her own. She is persuaded that it is her right to decide to have a child. In Nora's view, the church is usually suspicious of anything new and different. As biblical evidence to support her decision to go for artificial insemination, she cites the examples of Mary, Tamar and Rahab (Henry 2010:193-199).

On the last day of Nora's court case, the lawyers for the two sides persuasively argue their cases (Henry 2010:200-213). After the struggle with severe labour pains, Nora eventually delivers a baby boy (Henry 2010:214-217). The judge, supported by the church's constitution, gives the final verdict in favour of the church. Rev. Basil Newton accompanies Nora and Janet after the hearing session (Henry 2010:218-225).

Meanwhile, in the local news, there is a report about Rev. Newton being the father of Nora's baby. Newton then 
mentions his intention to resign. Amidst persisting requests from the church officials to disclose if he was indeed the father of Nora's baby, Newton refuses to answer the specific question. He promises that the resignation letter will follow in the coming week (Henry 2010:226-228).

Nora addresses an unnamed congregation about the need to cry. Amidst the many circumstances in life, people need to cry. She lists several examples on how Jesus listened and acted upon people's cries. As Nora goes through the aisle, amidst the singing of the song, 'lead me to the rock ...', Rico, her baby calls for her attention. Nora then holds him by the hand, with his father by her side. As they drive away, Rico asks Daddy when he would teach him to drive while Nora looks slyly and offers a chuckle (Henry 2010:229-235).

Reverend Mother's preceding narrative leads me to the following observations.

The maternal instinct may kick in at some point in one's life, overwhelming a female human being irrespective of her position as a woman of cloth. A burning desire to have a baby and not a man may persuade assertive women to do whatever it takes to fulfil such a desire. Reverend Mother, that is, Nora, provides readers with a perfect example of the preceding fact. The pertinent question for this article is: In a hetero-patriarchal space where church policy and the cultural prescripts prescribe only one space and one way in which conception, childbearing and normative motherhood should happen, how may women who choose to use unconventional means for childbearing fare? Nora's narrative has revealed that those who dare to go against the hetero-patriarchal grain can only reap the negative consequences emerging from such daring moves. In order to link Reverend Mother's narrative to a related biblical narrative, in the following section I ask whether Tamar's narrative (cf. Gn 38), 'the harlot turned heroine', casts more light on women who dare to conceive in unconventional ways? In my view, both Nora and Tamar are women whose deep desire to have babies, despite the motivations behind the desires, enables them to pursue unconventional means and eventually achieve their desired goals. I now turn to the story of Tamar.

\section{Casting a glance at Tamar in Genesis 38}

The story of Tamar is depicted as happening in Chezib, Enaim and Timnah in the hill country, with the latter located southeast of Jerusalem and northeast of Hebron in the eastern Shephelah (Cook 2001:117). Irrespective of the gaps in geography and time between Nora and Tamar's narratives, as well as the status that the Bible continues to enjoy as a normative book in varying African settings, Tamar's story is one of those which Reverend Mother cited to buttress her decision to do artificial insemination. Tamar was cited as one of the women who bore children outside the conventional boundaries set by the patriarchal status quo in ancient Israel. The children from the preceding mothers, though, eventually formed an important link for the lineage from which Jesus Christ would emerge.

Nora argues (Henry 2010):

And I dare anyone to get biblical ${ }^{2}$ with me! Mary the mother of Jesus got pregnant before her marriage to her husband, yet it is he that we serve and it is she that we revere. Rahab is listed as a female heroine in the scriptures and she was a prostitute - a prostitute who is an ancestor to Jesus! Tamar tricked her father in law into sleeping with her so that she could have a child - this Tamar too is an ancestor to Jesus! (p. 198)

Esther Fuchs' (1999a) argument appears to resonate with Nora's here:

Tamar must resort to wiles and guiles even in her selfless struggles for what is regarded as right and noble. Though decried in other circumstances, female deceptiveness in these narratives is portrayed as positive initiative and good sense. Tamar conceives male twins, Peretz and Zerah ... Peretz, son of Judah, is the ancestor of Obed, father of David - thus the patrilineal chain from Judah to King David is established and secured by the self-abnegation, wisdom, and loyalty of two helpless widows. (p. 79)

The reasons for my choice of the Tamar character as a closer character to resonate with Nora's story are slightly different though.

Firstly, Tamar desires to have a baby in accordance with the patriarchal expectations of the time. Niditch (2012) could thus argue:

On the one hand, this law might be interpreted as a malepreserving, male-protecting law, and Tamar's actions in 38:13-19 would be a wife's act of devotion to her dead spouse. (p. 42)

What comes to mind here are the opening verses of Genesis 38. The preceding verses foreground the conception and the birthing of babies by the wife of Judah, that is, Shua's daughter. The deliberate instruction by Judah to Onan to perform the duty of a levir for his deceased brother Er is also worthy of note. The question that could be posed, especially to feminist interpreters of Tamar's action to secure a baby at all costs, is whether her actions, contra the views of many a feminist scholar ${ }^{3}$, should also be viewed as having been inspired by her desire (cf. also Nora's) to have a baby rather than the pressure from the patriarchal status quo? The preceding possibility should not be ruled out.

The following assertion by Esther Fuchs (1999b) can thus be challenged:

Woman's reluctance to give birth or to assume maternal responsibility for her child are options which are completely

2.Perhaps Nora misses the important role of the father figure in the genealogies of biblical heroines like Rahab and Tamar (Mt 1:1-17; Rt 4:12, 18-21). Also, as Fuch (1999b:135) has argued, 'YHWH in the biblical narrative, restricts his interest in barren women to married women and to situations which leave no doubt as to the identity of the potential father'.

3.For example, Esther Fuchs (1999a) argues, Tamar does not act out of concern for her own well-being. She does not insist on marrying Shela, nor does she take initiative because she is lon to initiative because she is lonely or wants toget married. The text...takes great pains to emphasize that the heroines act selflessly. (p. 79). Did Tamar's maternal instincts not persuade her to desire to carry out her role as a mother The birth of childre in ancient Israel, as Meyer (1992:248) reminds us, would have been a source of joy to both men and women. 
excluded from the represented reality of the Bible. Onan, for example, refuses to 'raise seed unto "his brother $\mathrm{Er}^{\prime \prime}$ " and is consequently severely punished by YHWH (Gn 38:10). But a woman is not even shown to be capable of not desiring sons. The biblical narrative is careful to ascribe the desire for sons to its female figures. (p. 138)

As the biblical narratives are mostly written from a male perspective, it makes sense that even talk about what was or is biologically connected to female persons would have male undertones. These undertones, however, should not exclude the possibility that women would have desired to perform and also celebrate their motherhood role. I thus pose the following questions that seem to evade many feminist biblical scholars. Did women as mothers in pre-modern cultures (cf. also women in ancient Israel) not enjoy and celebrate their roles as mothers? Did they not take pride in having children? (cf. Meyer 1992). Did women not benefit from having children of both sexes, especially sons, for their economic support among other reasons? In African cultures (cf. also ancient Israelite cultures), the role of a woman as a mother was or is still celebrated by all, including the woman herself.

Secondly, the institution of the levir, which gets frustrated by Onan, is not strange to African cultural contexts. Also, apart from the levirate union, there exist certain marriage types that are geared at facilitating the role of a woman as a mother (Masenya [Ngwana' Mphahlele] 2010, 2013).

Thirdly, the unconventional nature of Tamar's action which is revealed in her relentless commitment to have a baby echoes Reverend Mother's unconventional means of conceiving a baby. Tamar's relentlessness in getting a baby is engaged with in the following section.

\section{Tamar, the Persistent and relentless mother to be?}

Genesis 38 opens with a note about Judah's marriage to a (nameless) daughter of a Canaanite man called Shua. What is expected in heterosexual marriage happens with success: sex $^{4}$, conception and the birth of sons. Judah's wife bears three sons, Er, Onan and Shelah. The wicked nature and actions of Er and Onan, respectively, claim their lives. Yahweh is the one who kills Judah's two sons (Gn 38:7, 10). Onan is punished by Yahweh for refusing to perform the duty of a levir ${ }^{5}$ on Tamar, the widow to Er. Judah had instructed his son, Onan, to perform the duty of a levir on Tamar, '[t]hen Judah said to Onan, "Go into your brother's wife and perform the duty of a brother-in-law to her; raise up offspring for your brother."'(Gn 38:8, NRSV).

4. Noteworthy is the fact that the usual term for sex, 'to know' (save for its use in Gn $38: 26)$, is not typical of this episode. Instead, 'to go into' is the typical phrase used (Gn $38: 2,8,16,18)$

5.It is important to note with Cook (2001:117) that '... While levirate marriage was not a law in the time of the ancestors (their family structure created and enforced the sanctions by which they lived), the custom of protecting the widow's place within her deceased husband's family, perpetuating the name of the deceased husband, and providing a son was commonplace in the ancient Near East (see Deut 25:5-10 for later law).
The actions of both brothers deprived Tamar of an opportunity to exercise her role as both a wife and a mother within the patriarchal context of her time.

It is not clear to the reader what challenge may be posed to the masculinity of the younger man when an older man instructs him to engage in sex and procreate, not for his own lineage, but for his deceased brother's. Onan was thus instructed to have sex with a woman, not by choice pending the availability of a designated female body. Would Tamar be available to play the role of a mother? Onan cannot be fully loyal to his father's instruction. Because of his unwillingness to deposit his seed for the sake of the perpetuation of his brother's lineage, thus also depriving Tamar of the possibility of performing the motherhood role, Onan decides to spill his semen whenever he ejaculated. Because of Yahweh's displeasure at the latter act, Onan is killed. Judah is scarred by the death of his second son and dismisses Tamar to do something unusual: return to her father's household and remain a widow indefinitely.

Tamar had lost her status as a virgin in her father's household and as a wife in her husband's household. Tamar's ambivalent position could not guarantee the possibility of performing her role as a mother. Such a position in Niditch's view (2012:42) was an anomaly because she was '... the young childless widow who has no hope of becoming a fruitful member of her husband's clan once the husband is dead'. Tamar thus plans and deliberately chooses to follow an unconventional path.

Meanwhile, Tamar's mother-in-law dies. After the mourning period, Judah, her father-in-law, would head to Timnah to shear his sheep. Tamar's earnest desire to have a baby and perpetuate Er's lineage causes her to put her widowhood garb off and wrap herself in a veil. Leaving the secluded private space of mourning, Tamar ventures into the public space, positioning herself in a way that would suggest her availability for sex (Bird 1989, 1999). Does she become a widow turned a prostitute? Did she deliberately pose in order to identify as a prostitute, or was the veil deliberately used to hide her identity from her father-in-law (Huddleston 2002:57-58)? Tamar determines to have sex not with any man, but with the right ${ }^{6}$ 'client'. Judah had not instructed his last born son, Shelah, to perform the duty of a levir on Tamar. She was thus deprived of an opportunity to conceive and bear a child within the acceptable conventional hetero-patriarchal confines.

Judah, thoroughly ${ }^{7}$ convinced that he sees a prostitute, asks for sexual favours from Tamar (Gn 38:16). Tamar's, unlike

6.As Fuchs (1999b:135) has rightly argued, "The only thing which saves her life and turns her into a biblical heroine is the fact that the man she sleeps with, Judah, is directly related to Er, her deceased husband, who left her with no children.'

7.The use of the adjective 'thoroughly' in this context would make sense only when we acknowledge with Phyllis Bird that the narrative depicted in Genesis 38 when we acknowledge with Phyllis Bird that the narrative depicted in Genesis 38 has a number of aetiological motives. Why? It cannot be realistic that Judah would not have recognised the vice of his daughter-in-law, as the two were making a deal before the action. Also, should the readers of the story assume that Tamar wore the veil consistently (or at all) during the act of intercourse? The text leaves its readers 
Nora's, would not be an artificial insemination. The deposit of Judah's seed would happen in a natural way, but within an unconventional space. From Judah's viewpoint, it would happen with an 'illegitimate' partner, who would have ironically authorised the whole endeavour. Could it be that the notion of hetero-patriarchal masculinity is being turned upside down by this female Other, who then controls when and with whom she could engage in productive sex? Fewell and Gunn (1993:89) say, 'He had sought to control her sexuality; in the final analysis, she controls his'. Tamar is careful to demand Judah's signet, cord and staff, 8 the three elements that marked Judah's identity. The preceding identity markers would later endorse Tamar's deliberate decision to be inseminated with the right seed from an unsuspecting 'donor'.

As noted elsewhere (Masenya [Ngwana' Mphahlele] 2006:486-499), Tamar's desire was not for sex (cf. also Nora's yearning not for a man, Henry 2010:117). Tamar's desire was for a baby. 'Surely her greatest desire is a means of conception' (Abasili 2016:157). Possibly, because of her maternal instinct, among other matters, Tamar desired to perform her role as a mother. For the narrator of her story, though, Tamar sought by all means to fulfil her role as the mother of male babies in a patriarchal context. The narrator's report on the birth of sons and the foregrounding of the institution of levirate union in the present episode points in that direction. The fact that Yahweh is also reflected as disapproving the spilling of male seed by killing the perpetrator points in the same direction. It thus occasions no surprise that after Judah was informed that the 'prostitute' was the same person as his daughter-in-law, he could remark, 'She is more right than I, since I did not give her to my son Shelah'. (Gn 38:26)

Tamar eventually gets what she wanted - a double portion, in fact - as she delivers male twins (Gn 38:27-30). Tamar becomes one of the 'veiled' women who can unsettle patriarchy (Fewell \& Gunn 1993):

Sometimes they refuse to be ignored. They have been known to be subversive. They can make a man lose confidence in himself (if only briefly!). They can even turn him into a laughing stock. They can occasionally force him to recognize his responsibility. And sometimes they can save his tribe and his/story. (p. 89)

As Tamar saves Judah's tribe, she finally gets what she wants, a baby!

\section{Conclusion}

\section{Any African biblical hermeneutics of motherhood?}

In African biblical hermeneutics, the biblical text and/or God-talk as based on the Christian Bible are deliberately

(footnote 7 continues...)

with no clues whatsoever regarding the answers to the preceding questions (Bird 1999). Or could it be a matter of Judah not having 'known' (Gn 38:26) Tamar, as Wunch (2012) would argue, 'and he did not know her again'. This not only speaks about not having any further sexual relations with her but also reminds the readers about not having any further sexual relations with her but also reminds the readers that he did not really 'know' her until now. He did not know her when he sent he away to the house of her father (because he thought her to be responsible for the ath of his sons) and he did not know her afterwards (because he thought her to be a prostitute) (p. 803).

8.For more details on the symbolic significance of garments and objects for use by selected women in the Jacob cycle, see Furman (1999) and Huddleston (2002). made to interact with the experiences of African-descended people in the process of Bible interpretation. Political, social, religious, economic and cultural aspects of the lives of African-descended people are critically engaged with in the Bible interpreters' engagement with the biblical text (Ukpong 2002; Adamo 2015). Based on the theme of this essay and the observations that were gleaned from the narratives of Nora and Tamar in the preceding paragraphs, the following questions may be asked: What insights may the narratives of Nora and Tamar shed on women's (joys and) struggles in engaging their roles as mothers in an alienating context such as a patriarchal one? How do women navigate the terrain between their exercise of choice on reproductive powers and the dictates of the heteropatriarchal status quo? What role do cultural sacred texts such as the Christian Bible and the church play in the affirmation and/or alienation of female human beings from their own bodies? Could present-day readers of the Nora and Tamar narratives get any helpful cues from these characters on the role of women as mothers?

\section{Motherhood: A celebrated role?}

The role of motherhood has been celebrated and continues to be celebrated by African women and men alike, in both ancient and modern times (Akintunde 2006; Labeodan 2015; Oduyoye 1995). Mbiti (1989) reminds us that in our African contexts:

To die without getting married and without children, is to be completely cut off from the human community ... to become an outcast and to lose all links with mankind [sic]. Everybody therefore must get married and bear children: that is the greatest hope of the individual for himself [sic] and of the community for the individual. (Mbiti1969:131)

In hetero-patriarchal contexts like the African and biblical ones, motherhood had and/or still has to be tied to heterosexual unions in which an identified, designated male person (read: father) has to be identified. Motherhood, as in the case of Nora, is celebrated for affording a female human being an opportunity to get to witness the fruit of her own womb. The desire that Nora had was not for a man, neither was it for sex. Reverend Mother's desire was to have someone who could keep company with her later in life. Nora's narrative reveals that assisted reproductive technologies, with their provision of a baby without the physical union between a man and a woman, enable women to lead successful lives as mothers without men, but ironically not without the male seeds.

Reading through the grain of Tamar's narrative, the reader is persuaded to believe that Tamar covers her face with a veil (which would in the context of the time have enabled her easy connection with a prostitute), in order to correct the injustices done on her by Judah. As Judah failed to provide Shelah to Tamar as a levir, and thus deprived Tamar an opportunity to perform her motherly role in a patriarchal context, Tamar decided to rectify the matter albeit in a deceitful way. However, as argued earlier on, one cannot rule 
out the possibility that just like in the case of Nora, Tamar's maternal instincts also had a share in her relentless effort to become a mother.

\section{Normative concepts of motherhood (and fatherhood)?}

As noted in the introduction, in traditional African contexts (cf. also in ancient Israelite contexts), legitimate motherhood is tied to heterosexual marriage in which a legitimate father figure is present. Interestingly, in both Nora's and Tamar's contexts, the true identity of the mother, the bearer of a baby for 9 months, did not seem to matter. The Seminary or church officials who challenged Nora about her decision to use assisted technology as a means through which to have a baby raised the concern that the baby born in such circumstances would lack a father figure. The claim made was that single-parented families, most of which are headed by women, basically do not function well because ideally children should be brought up by both male and female parents. The anonymity of the would-be father was also raised as a point of concern. What is ironic, though, is that within the last few pages of the book, the baby boy born to Nora is featured not only with his mother but also with his father: 'At the traffic light, three year old Rico asks, as he usually does. "Daddy, when are you going to teach me to drive?" Nora, as she always does, looks at Basil slyly and offers a chuckle' (Henry 2010:235).

As already noted in the case of Tamar, although she had to employ unconventional means to fulfil her motherly role, she had to make sure that the would-be father came from the correct clan, lest she would have risked being burnt for committing adultery as a (previously) married woman.

\section{Allergic to change? The challenge confronting the church}

A woman got pregnant in the church, the pastor and the Church Board decided to discipline her as she was not married. When the Church Board and pastor met the woman, she told them that she has stayed in the church for years and no one is marrying her and she is getting to her menopause so she went and did artificial insemination as she wants a child. She provided the medical documents that showed that she has done artificial insemination. The woman is pregnant without committing fornication or adultery.

If you were part of the Church Board, will you agree for her disfellowship (removal from register as it is called now)?

Give reasons for your answer (N. Shokane personal communication., 28 July 2017)

The preceding quote circulated on social media in July, 2017. One of the ladies from my church forwarded the chat to me because she wished to get my opinion on the matter. The gist of what the preceding text conveys resonates with the content of Nora's narrative. The main difference is that Nora was a pastor. Also, Nora informed the authorities about her intention to do artificial insemination.

What emerges from Nora's narrative and that of the woman depicted in the above chat though is the slowness with which transformation occurs in the church. The way the church handles the matters discussed in the previous paragraphs portrays it as an institution opposed to change. This is the case, especially as it pertains to its long-standing traditions on exegetical and hermeneutical matters. It should be seen as the Christian church in the true sense of the word. The preceding observation featured now and again within the narrative of Nora. A pertinent question, though, is: does resistance to change, especially if such change were to bear positive results for the marginalised, come from a genuine commitment to serving God or is it motivated more by human desire to cling to power, among other motivating factors?

The church pews, both on the African continent and its diaspora, are filled with female persons. However, male authorities are many a time vested with power to decide female matters, even those which affect women's personal lives. Nora (Henry 2010) could thus rightly remark:

But you know what I've noticed? Most of the battles in the church for the last half century have to do with women and their bodies; whether it is birth control or abortion or sex, or the matter of having children. It is always about us and our bodies, what we can do or cannot do. And it is always men who are telling us what is right from what is wrong as to what to do with our bodies, and our own sexuality. (p. 140)

For those who take comfort in being fundamentalist and biblicist, could there be any specific biblical text cited to condemn as sinners, women who employ assisted reproductive technologies? If not, why would such women be stripped of their ministerial credentials and/or removed from the fellowship of the church? From the experiences of the women in the two narratives, it is clear that those who choose to operate from a different and 'strange' perspective, those who dare to challenge traditional notions of childbearing and motherhood, can expect to face severe consequences.

\section{Unconventional motherhood and challenged masculinity?}

In (African) hetero-patriarchal cultures, the notion of worthy or ideal manhood is also linked to fatherhood. A real man is not only a husband, perhaps even a husband to many wives; he must also be a father, particularly a father to sons. The institution of levirate union reflected in Genesis 38 also points in this direction. Hetero-patriarchal notions of normative childbearing and motherhood would thus be linked with the existence of a father, in particular, a specific father for that matter. Judah had to make sure that the lineage of his deceased oldest son would be continued by his second son. It also occasions no surprise that when Tamar noticed that Judah had not fulfilled his promise of 
giving her to Shelah, she then decided to 'seek' sex not with any 'client' but with the right man. In the case of Nora, the issue of an unknown and absent father was also raised by the church authorities. The pertinent question to be asked here is: Could resistance to the use of assisted reproductive technologies be more of a reflection of the fears of men to no longer have control over female sexualities/bodies? Could there be a deep anxiety that such technologies would remove men (as fathers to babies) further and further away from the sacred space of female birthing and mothering? What may one make of men (who are instructed and/or expected, as in the case of Ruth also), to be the right go' els but show reluctance to do so (Gn 38:9)? Could it be that such men have a feeling that their masculinity is being challenged by those more powerful than they are?

In many a church setting, the distance between the sociohistorical contexts of biblical books and present-day Bible readers' contexts is usually not considered. Official Bible interpretation and the formulation of church policies and doctrines still remain mostly male prerogatives. The female constituencies, whose power is not legitimated by patriarchy, continue to fill the church pews. Also, as the Honoree Professor Eben H. Scheffler (2018:66-79) would, in his engagement with the gospel according to Luke, remind us that Jesus Christ was on the side of those on the margins, including women, perhaps it is only fitting to pose this question to him: Prof. Scheffler, which kind of hermeneutic would you recommend to a committed single Christian woman who, though she zealously desires to have a baby, finds herself trapped between 'artificial' infertility and a keen desire to conceive naturally and become a mother within a 'normative' hetero-patriarchal space?

\section{Acknowledgements}

I hereby acknowledge that this article is my own work and that it has not been published elsewhere before.

\section{Competing interests}

The author declares that no competing interest exists.

\section{Author contributions}

I declare that I am the sole author of this research article.

\section{Funding}

This research received no specific grant from any funding agency in the public, commercial, or not-for-profit sectors.

\section{Data availability statement}

Data sharing is not applicable to this article as no new data were created or analysed in this study.

\section{Disclaimer}

The views and opinions expressed in this article are those of the authors and do not necessarily reflect the official policy or position of any affiliated agency of the authors.

\section{References}

Abasili, A.I., 2016, The understanding of adultery in the Hebrew Bible: A critical survey, Alexander Izuchukwu Abasili, Xlibris, Dartford, UK.

Adamo, D.T., 2015, 'The task and distinctiveness of African biblical hermeneutic(s)', OTE 28/1, 31-52.

Akintunde, D.O., 2006, 'Women as healers: The Nigerian (Yoruba) example', in I.A Phiri \& S. Nadar (eds.), African women, religion and health: Essays in honor of Mercy Amba Ewudziwa Oduyoye, pp. 157-169, Cluster, Pietermaritzburg.

Bird, P.A., 1989, 'The Harlot as Heroine: Narrative art and social presupposition in three Old Testament texts', Semeia 46, 119-139.

Bird, P.A., 1999, 'The harlot as Heroine: Narrative art and social presupposition in three Old Testament texts', in A. Bach (ed.), Women in the Hebrew Bible: A reader pp. 99-117, Routledge, New York.

Cook, J.E., 2001, 'Tamar, Judah, Joseph and Potiphar's wife: A literary study of Genesis 38-39', Proceedings EGL \& MWBS 21, 115-128.

Fewell, D.N., 1993, Gender, power, \& promise: The subject of the Bible's First Story, Abingdon, Nashville, TN.

Fuchs, E., 1999a, 'Status and role of female heroines in the biblical narrative', in A Bach (ed.), Women in the Hebrew Bible: A reader, pp.77-84, Routledge, New York.

Fuchs, E., 1999b, 'The literary characterization of mothers in the Hebrew Bible', in A. Bach (ed.), Women in the Hebrew Bible: A reader, pp. 127-139, Routledge, New York.

Furman, N., 1999, 'His story versus her story: Male genealogy and female strategy in the Jacob Cycle', in A. Bach (ed.), Women in the Hebrew Bible: A reader, pp. 119-126, Routledge, New York.

Henry, E., 2010, Reverend mother, Eron Henry, Charleston, SC.

Huddleston, J.R., 2002, 'Divestiture, deception and demotion: The garment motif in Genesis 37-39', JSOT 98, 47-62. https://doi.org/10.1177/030908920202600403

Niditch, S., 2012, 'Genesis', in C. Newsom, S. Ringe \& J. Lapsley (eds.), Women's Bible commentary: Twentieth anniversary edition: Revised and updated, pp. 27-45, Westminster John Knox, Louisville, KY.

Masenya (Ngwana' Mphahlele), M., 2004, How worthy is the woman of worth? Rereading Proverbs 31:10-31 in African-South Africa, Peter Lang, New York.

Masenya (Ngwana' Mphahlele), M., 2006, 'Killed by aids and buried by religion', OTE 19(2), 486-499.

Masenya (Ngwana' Mphahlele), M., 2010, 'Is Ruth the 'êšethayil for real? An exploration of womanhood from African proverbs to the threshing floor (Ruth 3:1-13)', Studia Historiae Ecclesiasticae XXXVI(Suppl), 253-272.

Masenya (Ngwana' Mphahlele), M., 2013, 'Engaging with the Book of Ruth as single African Christian Women: One African Christian Woman's Reflection', Verbum et Ecclesia, 34(1), 9. https://doi.org/10.4102/ve.v34i1.771

Mbiti, J.S., 1989, African religions and philosophy, Heinemann, Oxford.

Meyer, C., 1992, 'Everyday life: Women in the period of the Hebrew Bible', in C.A. Newsom \& S. Ringe (eds.), The women's Bible commentary, pp. 244-251, Westminster/John Knox Press, Louisville, KY.

Labeodan, H.A., 2015, 'Exploring Yoruba Proverbs with feminine Lexis as a tool for reimagining African womanhood', in R. Ross \& R. Emega-Eteko (eds.), Unraveling and reweaving sacred Canon in Africana womanhood, pp. 21-34, Lexington Books, Lanham.

Ruether, R.R., 1994, Religion and God-talk, Beacon, Boston, MA.

Oduyoye, M.A., 1995, Daughters of Anowa: African women and patriarchy, Orbis, Maryknoll, NY.

Scheffler, E.H., 2018, 'Women in the Gospel of Luke', in E.H. Scheffler \& M. Masenya (Ngwana' Mphahlele) (eds.), Study guide 1 for OTS 3704, pp. 66-81, Unisa, Pretoria.

Ukpong, J.S., 2002, 'Reading the Bible in a Global village: Issues and challenges from African readings', in J.S. Ukpong, M.W. Dube, G.O. West, A. Masoga, N.K. Gottwald \& J. Punt et al. (eds.), Reading the Bible in the global village: Cape Town, pp. 9-39, SBL, Atlanta, GA.

Wunch, H.-G., 2012, 'Genesis 38-Judah's turning point: Structural analysis and narrative techniques and their meaning for Genesis 38 and its placement in the story of Joseph', OTE 25/3, 777-806. 